\title{
株枯病菌を接種したイチジク苗木に抢ける病徵の進展過程 （2）宿主細胞の防御反応と内部病徵飞関する解剖学的検討
}

\author{
隅田 㿞月 ${ }^{1}$ ・梶井 千永 ${ }^{2} \cdot$ 森田 剛成 ${ }^{3}$ ・黒田 慶子 ${ }^{1 *}$
}

\begin{abstract}
SUMIDA, S. ${ }^{1}$, KAJII, C. ${ }^{2}$, MORITA, T. ${ }^{3}$ and KURODA, K. ${ }^{1 *}$ (2016). Disease development in Ficus carica seedlings after inoculation with Ceratocystis ficicola. (2) Microscopic analysis of the host-pathogen interaction and internal symptoms. Jpn. J. Phytopathol. 82: 310-317.

Ceratocystis ficicola is causing serious wilt disease in many fig orchards in Japan. To elucidate the mechanisms of disease development, we inoculated fig cuttage seedlings with the pathogen and periodically harvested stems for light microscopy to examine the distribution of $C$. ficicola and responses of host cells before the start of wilt symptoms. As shown by yellow to brown staining of the xylem in fig stems, secondary metabolism was activated in axial and ray parenchyma cells adjacent to hyphae, then the metabolites were secreted into vessels. Above $5 \mathrm{~cm}$ from the inoculated holes, few or no hyphae were observed, and accumulation of secondary metabolites was not extensive. When leaf wilting started, hyphae were abundant in the discolored xylem in which secondary metabolites had accumulated. In contrast, the cambium was not necrotic before the wilt symptoms. Symptoms developed as follows: (1) Hyphae of the pathogen elongate in vessels and invade the adjacent parenchyma cells. (2) Secondary metabolism is activated in parenchyma cells. (3) Dark brown discoloration occurs in xylem when the secondary metabolites are produced, and vessels become dysfunctional in the discolored areas. (4) Water supply to leaves decreases, and the wilt symptom starts.
\end{abstract}

(Received October 30, 2015; Accepted March 28, 2016)

Key words: Ceratocystis ficicola, Ficus carica, wilt disease, xylem dysfunction, secondary metabolites

\begin{abstract}
諸言
イチジク株枯病（以下，本病）は，日本全国の主要なイ チジク産地で発生して打り，イチジク成木を枯死に至らし めることから，深刻な病害であると位置付けられる（梶谷, 1992; 清水ら，1999）。株枯病菌（Ceratocystis ficicola，以下 本菌）に感染した個体は，地際部の主幹や主枝に不規則な 大型円形の茶褐色〜黒褐色の病斑が生じ，葉の黄変および 萎调が生じた後, やがて落葉枯死することが報告されてい る（瓦谷・三輪，2012; 清水ら，1999; 外側ら，1999）。本菌 は土壤伝染が主因と言われてきたが，近年アイノキクイム
\end{abstract}

シによる虫媒伝染の可能性が指摘された（梶谷，1996）。乙 かし, 生産現場では, 本病の被害に気付いた時点ではアイ ノキクイムシの加害から月日が経過して扮り, 感染が土壌 由来なのかアイノキクイムシ由来なのか判別できないこと がある（新田ら，2005）。そのためか，アイノキクイムシに よる伝染の可能性を含めず，土壌伝染木であることを前提 とした報告が多い（清水ら，1999）。本病への対策として抵 抗性台木や薬剤を活用した防除技術が開発されている（細 見，2009; 清水ら，1999）が，現状では発病阻止は困難であ る（森田ら，2012），今後，より効果的な防除技術を開発す るには，基礎的知見として感染から発病までの仕組みの解

1 神戸大学大学院農学研究科（ 657-8501 神戸市灘区六甲台町 1-1） Graduate School of Agriculture, Kobe University, 1-1 Rokkodai, Nada-ku, Kobe 657-8501, Japan

2 チョーヤ梅酒株式会社（广 583-0841 大阪府羽曳野市駒ヶ谷 160-1） Choya Umeshu CO. LTD., 160-1 Komagatani, Habikino-shi, Osaka 583-0841, Japan

${ }^{3}$ 広島県立総合技術研究所農業技術センター果樹研究部（テ 739-2402 広島県東広島市安芸津町三津 2835） Fruit Tree Research Division, Agricultural Technology Research Center, Hiroshima Prefectural Technology Research Institute, 2835 Mitsu, Akitsu-cho, Higashi-Hiroshima, Hiroshima 739-2402, Japan

* Corresponding author (E-mail: kurodak@garnet.kobe-u.ac.jp) 
明が必要であると考えた。

アイノキクイムシの本病への関与については懐疑的な見 方もあったが, 森田ら（2012）はアイノキクイムシの宿主 への穿入と固場内の本病被害拡大状況を追跡し, 穿入後に 萎淍症状が発生していることを示した. さらにKajii et al. (2013) は，萎调開始時点のアイノキクイムシ穿入部の 顕微鏡観察によって, 外部病徵の発現と内部病徵の進展と の関係を探り, アイノキクイムシの孔道に沿って病原菌が 分布を拡大していること, 孔道形成が木部の変色拡大を助 長していることを明らかにした。 また, 本病に扣ける養菌 性キクイムシの関与や樹幹木部の変色といら特徵は, 森林 のナラ類やカシ類に集団枯死を引き起こすブナ科樹木萎调 病（ナラ枯れ）に見られる現象と類似していることを指摘 した.ナラ枯れの発病過程について, 黒田・山田（1996）は, 「病原菌の作用により, 樹幹のある高さで水平方向に変色部 が広がり, 通水機能が全面的に停止する部位が出現し, そ の部位より上部の水の供給が滞ることで萎调に至る」と説 明している. Kajii et al. (2013) はこのよらな病徵進展の類 似性から, 本病を萎调病であると指摘した。しかし, 萎调 が開始したイチジク自然感染木の観察だけでは, 萎调に至 るまでの内部病徵を経時的に追跡できなかった。

そこで筆者らは, イチジク苗木の幹部への有傷接種実験 を行った。森田ら（2016）はまず, 本菌接種苗木では接種 $2 \sim 3$ 週間後に葉の萎调症状が発現し枯死に至ったこと, 萎 调および枯死個体には接種したC. ficicola の子のら殼が形成 されたことから，本菌の接種により発病・枯死したことを 確認した. さらに, 接種苗木に颃ける通水機能の変化に関 して, 根から色素液を吸わせて観察を行った結果, 葉の萎 调開始時には通水機能が著しく低下していることを確認し, この現象が感染により起こったものであると推察した。 た, 通水機能低下個体では接種部位付近の木部で変色部が 広がっていた. この変色部は自然感染・枯死木に常に観察 される (Kajii et al., 2013). これは一般に傷害心材と呼ばれ, 微生物等や傷に対する防御反応として樹木組織内で二次代 謝産物の生成が活発になることで形成され，通常の心材と 同様に通水機能は失われていることがわかっている（Hillis, 1987)。このことから，木部に変色部が広がり通水機能が低 下し，枝葉への水分供給が滞ったと推測した.

このよらに，本菌がイチジクの通水機能の低下に関わる ことが森田ら（2016）により示されたが，本菌による影響 で褐変が生じたのかは肉眼観察だけでは明確に説明できな い.つまり，本菌が宿主細胞に及ぼす影響については不明 なままであり, 光学顕微鏡により観察する必要があった. 本研究では森田ら（2016） と同じ接種苗木を供試し，「変色
部」および「通水停止範囲」では何が起こっているのか, そして発病に至るまでの現象やその仕組みについて検討し た。本供試木は，主幹組織への感染が起こった場合を想定 した主幹部への有傷接種を行っている，褐変の拡大につい ては，接種点付近の木部で著しかったため（森田ら，2016）， 特に接種部位を中心に解剖を行った。な怔，土壤伝染の場 合の侵入経路と発病までのプロセスについては, 隅田ら （2016）を参照されたい. 樹木細胞の反応については，二次 代謝産物の生成にあたり柔細胞類内の貯蔵糖類量が減少す ることや，道管内には充填物がみられることなどが報告さ れている（Holbrook and Zwieniecki, 2005）ので，それらに 注目して観察を行った.

\section{材料と方法}

供試木への接種と採取および試料処理 イチジク品種「蓬 莱柿」の 2 年生苗を供試木とした。その一部には，森田ら （2016）の研究に用いた供試木を含む. 2011 年 6 月 7 日に 一年枝をポット内に充填した培土(ハイポネックス ${ }^{\circledR}$ 培養土) に挿し木し，2012 年 9 月の接種日まで育成した。苗木の総 本数は 40 本であり, 接種時の供試木の平均樹高は $103 \mathrm{~cm}$, 平均茎径は $17 \mathrm{~mm}$ であった。株枯病菌（広島 $\mathrm{cf06}$ 株）を $\mathrm{PDA}$ 平板培地で $2 \sim 3$ 週間前培養 $\left(25^{\circ} \mathrm{C}\right.$ 全暗）して形成さ れた菌叢上に，滅菌爪楊枝（長さ $7 \mathrm{~cm}$, 径 $2.2 \mathrm{~mm}, 0.5 \%$ 酵母エキス含有 PDB 培地に浸漬しオートクレーブ処理）を 静置して約 15 日間培養し, 接種源とした. 2012 年 9 月 5 日, 苗木主幹部に病原菌の接種を以下のように実施した。苗木 の主幹中心部に電動ドリルで貫通穴（直径 $3 \mathrm{~mm}$ ）を 4 ヶ所 開けて，穴に爪楊枝を突き通すことで接種した（Fig. 1).

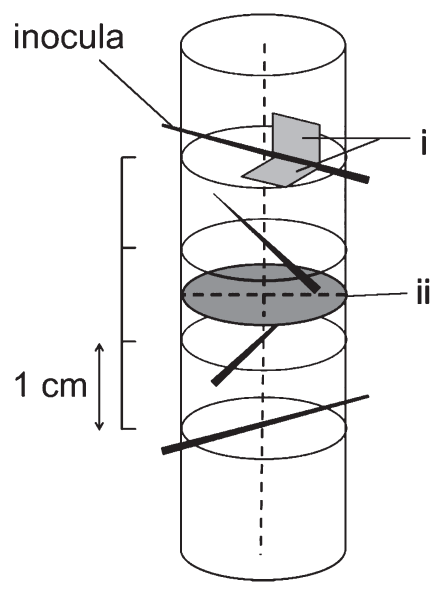

Fig. 1. Diagram of inoculation of Ficus carica with Ceratocystis ficicola and anatomy (i, ii). i: Cross and radial sections adjacent to the uppermost inoculation hole. ii: Cross section at center of inoculation area. 
また，対照区として無傷無接種木，滅菌爪楊枝を刺した有 傷無接種木を準備した。本菌接種木は, 接種 4 日後および 7 日後以降 42 日後まで 7 日間隔で各 2 ４本を採取した. 対 照の有傷無接種木と無傷無接種木は接種当日, 3 週間後, 6 週間後に $2 \sim 4$ 本採取した.

光学顕微鏡試料の作製および観察方法 栽培ポットから 抜き取った供試木を約 $5 \mathrm{~cm}$ の長さに切断した状態で FAA $(40 \%$ ホルマリン: 酢酸 : $50 \%$ エタノール $=5: 5: 90 \mathrm{v} / \mathrm{v})$ に浸して固定し，以下の手順でプレパラートを作製した. 試料片を 12 時間程度水洗した後に, 滑走式ミクロトーム（リ トラトーム REM-710 : 大和光機工業）を用いて厚さ $20 \mu \mathrm{m}$ の切片を作製した. 本菌の侵入に反応して生成された宿主 細胞の着色物質を観察するために, 無染色切片のプレパラー トを作製した。また, 宿主細胞の生死やでんぷん粒の貯蔵 の有無, 菌系の分布を観察するために, PAS・トルイジンブ ルー二重染色（Feder and O'Brien, 1968）を行った. 作製し たプレパラートは光学顕微鏡（Nikon ECLIPSE Ni-u）で観 察し，デジタルカメラ（Canon EOS 60D, Canon EOS Kiss X70）で撮影した.

光学顕微鏡観察および画像解析 宿主内での本菌の接種 位置からの分布拡大状況を微細なレベルで把握するために, 接種 4 日後, 7 日後, 14 日後, 21 日後, 有傷無接種 21 日 後各 3 4 個体を対象とし, 爪楊枝の接種穴部分を含む横断 面扎よびその面に直角の放射断面 $3 \times 3 \mathrm{~mm}$ 範囲（Fig. 1-i）を顕微鏡で観察した。 また，本菌の侵入による宿主細 胞の反応を把握するため, 前述の範囲において, 二次代謝 の活性化に起因する着色物質の蓄積や, 二次代謝エネルギー として消費されるでんぷん粒の分布を観察した. $3 \times 3 \mathrm{~mm}$
の範囲内をさらに $50 \times 50$ の区画 $(1$ 区画 $60 \times 60 \mu \mathrm{m})$ に分け, 画像処理ソフトウェア（Photoshop）を用いて，以下の手順 で感染の影響の有無を記録した。(1)菌系または胞子がみら れた区画，(2)宿主細胞に感染への反応があり着色等がみら れる区画, (3)変化が認められない区画とした。 これらの区 画を色分けし, 細胞の着色面積および菌糸の分布面積を図 示した.

加えて，葉に萎调症状が発現した段階についても接種部 （Fig. 1-ii）を顕微鏡で詳細に観察し，宿主細胞の状態を有傷 無接種と対比して把握した.

また，森田ら（2016）が子のら殼の形成によって確認し た本菌の分布範囲は接種点から上下方向に $10 \mathrm{~cm}$ 程度で あったことから，接種部から垂直方向に $5 \mathrm{~cm}$ 扎よび $10 \mathrm{~cm}$ 離れた位置に打ける本菌の分布と宿主細胞の変化について 顕微鏡で観察し，接種部位の変化との関連や，接種点から 離れた位置で見られる時間的な差などについて検討した.

\section{結 果}

\section{接種部における本菌の分布と宿主細胞の反応の経時的変化}

接種 4 日後, 7 日後, 14 日後, 21 日後個体の接種穴部分 を含む横断面执よび放射断面 $3 \times 3 \mathrm{~mm}$ （Fig. 1-i）の範囲内 に扣ける菌系や胞子の分布と, 宿主細胞の二次代謝活性化 に起因する着色物質の分布を詳細に観察した結果，以下の よらな傾向がみられた。

まず，菌糸や胞子の分布は，接種 4 日後には横断面にも 放射断面にも観察されなかった (Fig. 2c, d). 接種 7 日後でも, 横断面では菌糸や胞子は観察されなかったが (Fig. 2e), 放 射断面では接種穴から $0.5 \mathrm{~mm}$ 離れたところまで菌糸が認め

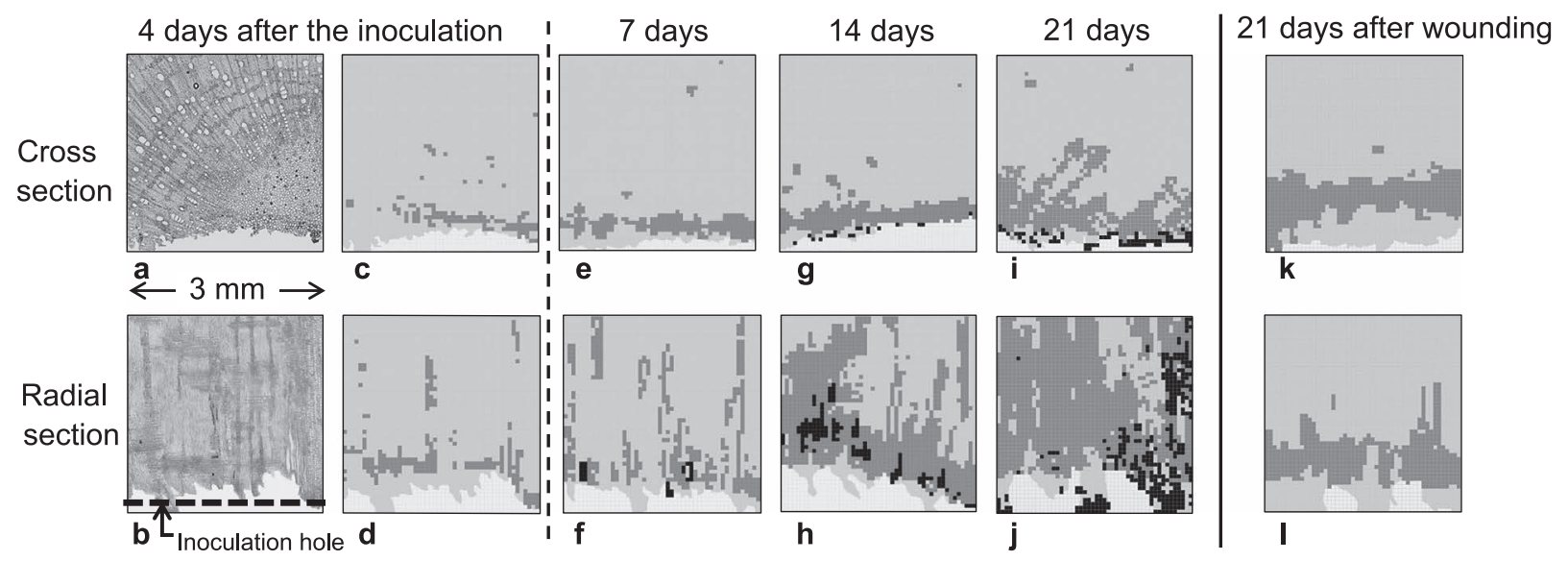

Fig. 2. Distribution of hyphae and secondary metabolites around the inoculation holes (Fig. 1, i) in the tissue of $F$. carica. Light grey: Fig tissue without metabolites, dark grey: distribution of secondary metabolites, black: distribution of hyphae. a, b: Light micrographs (LMs). c-1: Traces of hyphae and secondary metabolite distribution from LMs. These are representative of 3 or 4 seedlings. 


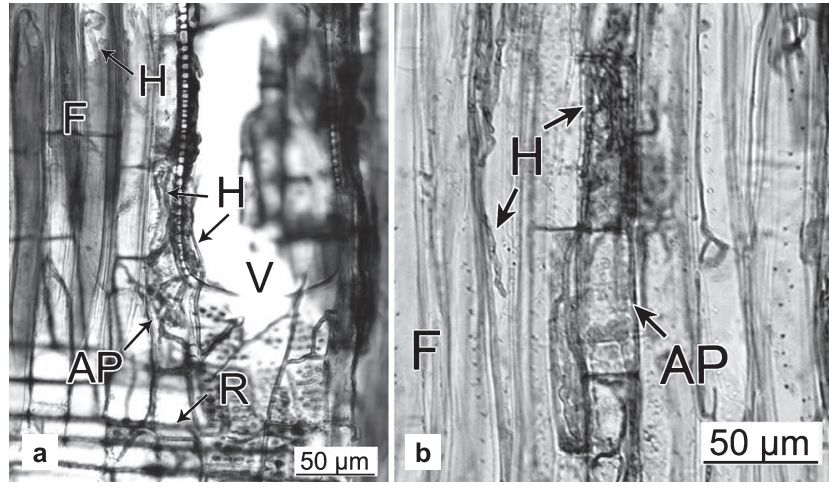

Fig. 3. Distribution of hyphae around the inoculation holes (Fig. 1, i) in sections stained with periodic acid-Schiff's reagent and toluidine blue $\mathrm{O}$.

a: Hyphae in vessels and surrounding axial parenchyma cells, ray parenchyma cells and fiber cells, 7 days after inoculation (dai).

b: Hyphae observed in axial parenchyma cells and fiber cells apart from vessels, 14 dai.

AP, axial parenchyma cells; F, fiber cells; $H$, hyphae; R, ray parenchyma cells; V, vessels.

られた (Fig. 2f). 菌糸は道管内括よび隣接する軸方向柔細胞, 放射柔細胞，木部繊維内に観察された（Fig. 3a）。接種 14 日 後には, 横断面では菌系や胞子が接種穴に接する部位で認 められる程度であり（Fig. 2g），放射断面では接種穴から 1.5〜 $3 \mathrm{~mm}$ 離孔たところまで認められた（Fig. 2h)。菌系は道管 内のほか, 道管から離孔た軸方向柔細胞, 放射柔細胞, 木 部繊維にも観察された（Fig. 3b)。接種 21 日後には, 横断 面では 14 日後と同様に菌系や胞子が接種穴に接する部位で 認められる程度であり（Fig. 2i），放射断面では接種穴から $3 \mathrm{~mm}$ 離れた部分まで菌系や胞子が観察され, 観察範囲内の 分布密度は 14 日後よりも高かった（Fig. 2j)。菌系は道管内 の浪か，道管から離孔た軸方向柔細胞，放射柔細胞，木部 繊維にも観察された。

二次代謝活性化に起因する着色物質の分布は，接種 4 日 後には, 横断面では接種穴から $1 \mathrm{~mm}$ (Fig. 2c), 放射断面 では $3 \mathrm{~mm}$ (Fig. 2d）離孔た範囲まで認められた。軸方向抏 よび放射柔細胞内に黄色い二次代謝物質の蓄積が観察され, 隣接する道管の壁が黄色く着色していた（Fig. 4a). 接種 7 日後には, 二次代謝活性化による着色物質の分布は, 横断 面では接種穴から $1 \mathrm{~mm}$ (Fig. 2e)，放射断面では $3 \mathrm{~mm}$ (Fig. 2f）の範囲に認められ, 接種 4 日後よりも観察範囲内の着 色の分布密度が高かった. また， 4 日後と同様に，軸方向お よび放射柔細胞内に黄色い二次代謝物質の蓄積があった注 か, 道管だけでなく木部䋊維の壁が黄色く着色していた（Fig. 4b). 接種 14 日後には, 二次代謝活性化による着色物質の
分布は, 横断面では接種穴から $1 \mathrm{~mm}$ (Fig. 2g), 放射断面 では $3 \mathrm{~mm}$ （Fig. 2h）の範囲に認められた．着色は菌系の周 囲を囲むよらに分布して沏り, 接種 7 日後より 観察範囲 内の着色の分布密度が高い傾向にあった．軸方向拈よび放 射柔細胞の浪か，木部繊維内や道管内に黄色～褐色の物質 の充填が観察された（Fig. 4c, d)。接種 21 日後には，二次 代謝活性化による着色物資の分布は，横断面では接種穴か ら 1 2 mm の範囲（Fig. 2i）, 放射断面では観察範囲全体に 広がって打り接種 14 日後よりも着色の分布密度が高い傾向 にあった（Fig. 2j），一方で，付傷のみで菌を接種していな い有傷無接種個体を観察したところ，付傷 21 日後の二次代 謝活性化による着色物質の分布は, 横断面では付傷穴から $1 \mathrm{~mm}$ の範囲（Fig. $2 \mathrm{k}$ ), 放射断面では $1.5 \mathrm{~mm}$ の範囲を中心 に認められた（Fig. 21）。付傷部付近の軸方向拈よび放射柔 細胞，木部繊維，道管内に黄色い物質が観察された．観察 範囲内の着色の分布密度は, 横断面では接種 14 日後と同程 度であり, 綐断面では接種 14 日後よりも低い傾向にあった (Fig. 21)。また，観察した各時系列の接種個体，有傷無接種 個体全てに打いて，接種拉よび付傷穴隣接部の，穴開け時 にドリルで破壞された柔細胞類の内部には有色の物質の蓄 積は認められなかった。

二次代謝エネルギーとして消費されるでんぷん粒につい て観察したところ，接種 4 日， 7 日，14 日後拈よび 21 日後 の試料では，二次代謝物質の蓄積が見られない柔細胞内に はでんぷん粒が密に存在しているのが認められた（Fig. 4e). 一方，黄色〜褐色の二次代謝物質が認められた柔細胞 内には，でんぷん粒は認められなかった（Fig. 4f).

\section{外部病徵発現時における接種部の宿主細胞の状態}

接種 21 日後の萎调開始個体の接種部（Fig. 1-ii）木部に変 色が広がって抢り（森田ら，2016），顕微鏡で観察すると， 菌糸が道管, 木部䋊維, 軸方向扔上び放射柔細胞内に観察 され，菌糸が認められた細胞拉よびその周囲の細胞内に， 二次代謝活性化に起因する黄色〜褐色の着色物質が観察さ れた（Fig. 5a）。また，道管内にはチロースの充填が認めら れた。菌系の侵入がある細胞および着色物質の蓄積された 柔細胞は, 核が縮小あるいは認められないこと, 菌糸が細 胞内を充填していることなどから，すでに壊死しているこ とは明らかであった．変色部に隣接する形成層抒よび師部 の柔細胞は，核が認められないことや褐変などから壊死が 明らかであったが，変色部と隣接していない形成層細胞内 には，核が存在しているものが多くみられた（Fig. 4g)，変 色が認められなかった木部では，軸方向および放射柔細胞 に淡褐色の着色物質が認められたが, 菌の分布は観察され なかった。 

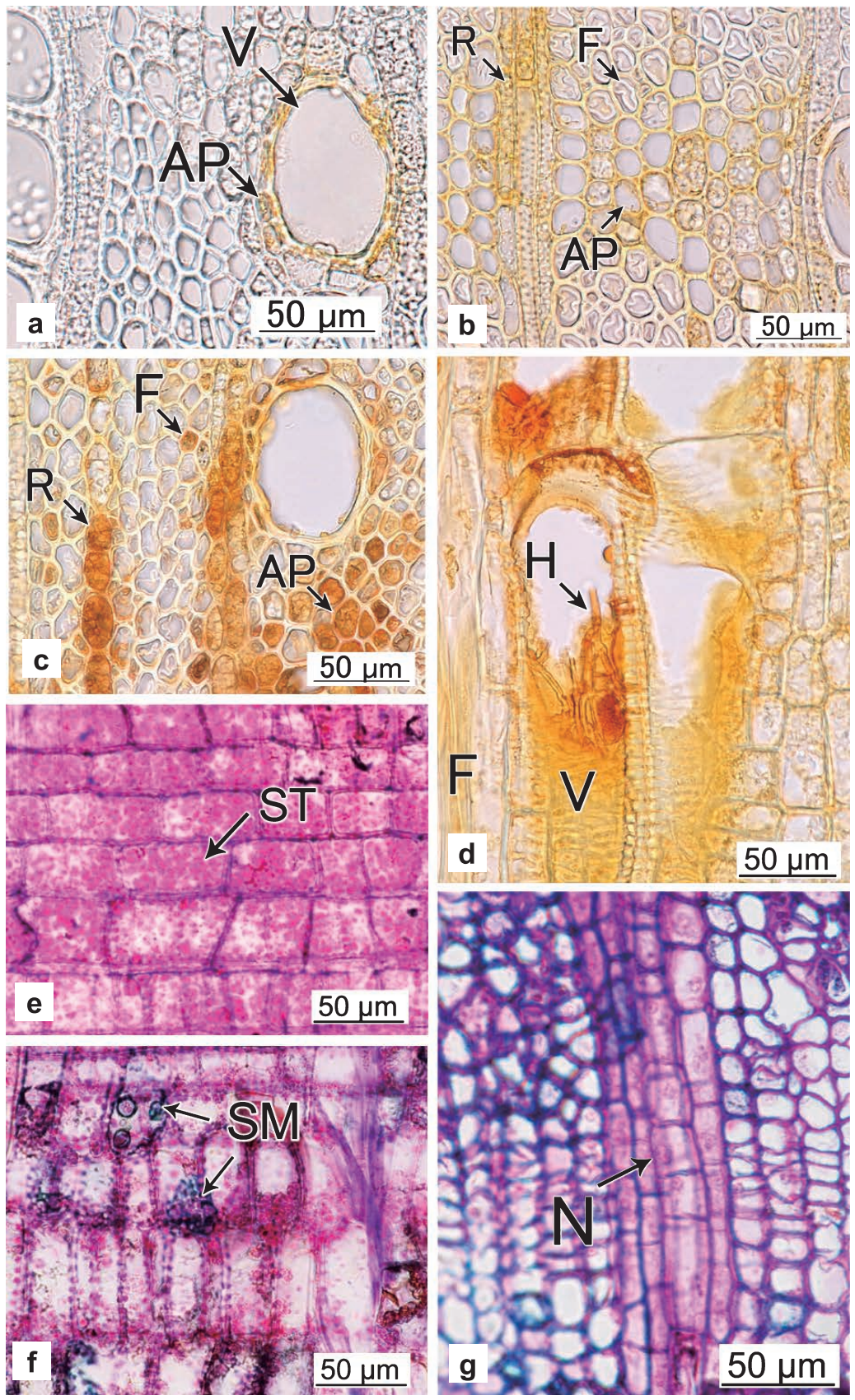

Fig. 4. Secondary metabolites stained around inoculation holes (Fig. 1, i) and nucleus in cambial cells at inoculation area (Fig. 1, ii). a: Accumulation of yellow secondary metabolites in axial parenchyma cells and staining of cell walls of the surrounding vessels, 4 days after inoculation (dai). b: Accumulation of yellow secondary metabolites in axial parenchyma cells, ray parenchyma cells and staining of cell walls of fiber cells, 7 dai. c: Accumulation of brown secondary metabolites in axial parenchyma cells, ray parenchyma cells, and fiber cells, 14 dai. d: Dense accumulation of yellow to brownish secondary metabolites in vessels, 14 dai. e: Starch in ray parenchyma cells without accumulation of secondary metabolites, 14 dai. f: Ray parenchyma cells with accumulation of secondary metabolites, 14 dai. Starch staining was not observed. g: Nucleus in cambial cells at start of leaf wilting. AP, axial parenchyma cells; F, fiber cells; H, hyphae; N, nucleus; R, ray parenchyma cells; SM, secondary metabolites; ST, starches; V, vessels. a-d: No stain applied. e-g: Sections were stained with periodic acid-Schiff's reagent and toluidine blue O.

付傷 21 日後の有傷無接種個体では, 付傷部（Fig. 1-ii）付 近には肉眼で認められる変色はほとんどなく（森田ら, 2016)，顕微鏡で観察すると軸方向柔細胞，放射柔細胞に淡
褐色の着色が認められる程度であった（Fig. 5b). なお，色 素水の根からの吸入により，付傷による著しい通水阻害は なかったことがわかっているが（森田ら，2016），色素水に 


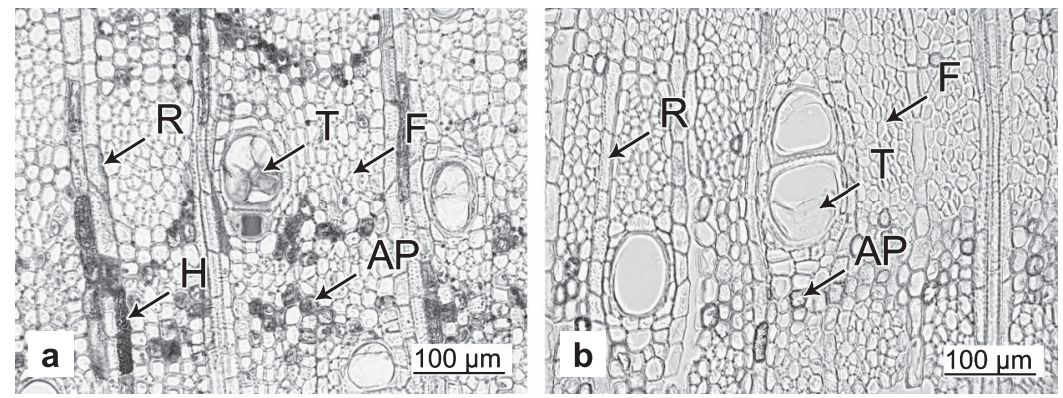

Fig. 5. Secondary metabolites at inoculation area (shown in Fig. 1, ii).

a: Brownish secondary metabolites in axial and ray parenchyma cells and vessels at start of leaf wilting, 21 days after inoculation (dai). b: Xylem tissue without secondary metabolites in noninoculated control sample, 21 days after wounding. AP, axial parenchyma cells; F, fiber cells; $\mathrm{H}$, hyphae; $\mathrm{R}$, ray parenchyma cells; T, tyloses.

より赤く染色されなかった範囲では, 潘ぼ全ての道管内で チロースの充填が観察された. 一方で，赤く染色された通 水のある範囲では, 道管内にチロースの充填は活とんぞ観 察されなかった。

\section{子のう殼の形成部位における宿主細胞の反応}

接種部から $5 \mathrm{~cm}$ 抢よび $10 \mathrm{~cm}$ 上部，つまり試料採取後に 子のら殼の形成によって本菌の分布が確認された部位を顕 微鏡で観察した。接種 7 日後の接種部から $5 \mathrm{~cm}$ 離れた本菌 検出部位では, ごく局所的に道管内に菌系が観察された (Fig. 6). また, 着色物質の蓄積は軸方向柔細胞およびその周囲 の道管内腔に，ごく局所的に認められた。接種部から $10 \mathrm{~cm}$ 離れた本菌検出部位では, 主幹横断面捻よび放射断面の切 片上では菌系は確認できなかった，宿主細胞内における着 色物質の蓄積も明膫には認められなかった。

萎调が開始した個体では, $5 \mathrm{~cm}$ 扣よび $10 \mathrm{~cm}$ 上部で菌系 が道管内のほか，軸方向抢よび放射柔細胞内に観察され， 二次代謝に起因する着色物質が軸方向扣よび放射柔細胞, 道管，木䋊維内にみられた。 しかし，前述の接種部（Fig. 5a) でみられるほどに着色物質の蓄積範囲は広がっていなかった。

\section{考察}

森田ら（2016）は，株枯病菌 C. ficicola を接種した苗木内 で菌の分布や木部の変色が拡大寸るとともに外部病徴であ る葉の萎调が開始することを明らかにし，それらの萎调個 体から C. ficicola を再検出して, この菌が発病・枯死に関わっ ていることを示した。 また，苗木の組織内部で起こる木部 の褐変現象が自然感染木で観察される現象 (Kajii et al., 2013）と共通していると報告した。本研究では, 同じ試料 を顕微鏡で観察することにより，株枯病菌の伸長，分布々 宿主細胞の変化，それらと水分通導の停止抒よび萎调との 関係について森田ら（2016）の結果と突き合わせながら詳 細に記載した.

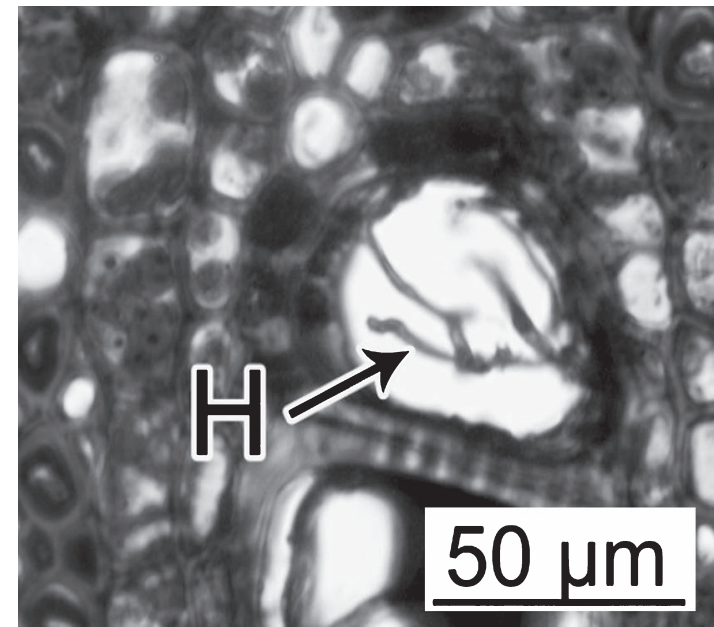

Fig. 6. Hyphae $(\mathrm{H})$ in vessels $5 \mathrm{~cm}$ from the inoculation area, 7 days after inoculation.

接種した菌の動態や宿主への生理的な影響については, まず， $3 \times 3 \mathrm{~mm}$ の狭い範囲で観察した結果から以下のこと が明らかになった，接種 7 日後には，菌糸は筒状の道管の 開口部から侵入し垂直方向に伸長していたのに対して，横 断切片上で菌糸の分布が確認できなかった．これは，本菌 が接種穴から水平方向に伸長していなかったことを示して いる，道管のような空洞が水平方向にはないため，菌系が 水平方向に伸長するには多くの細胞壁を突破する必要があ り，菌系の伸長が物理的に困難であったと考光られる．7日 後の放射断面で放射柔細胞への菌系の侵入が認められたこ とから，水平方向への伸長は放射柔細胞を介して可能では あるが，道管を介する伸長よりも頻度が極めて低いと考兄 られる. 接種 14２1 日後は，水平方向上りも垂直方向の菌 の分布密度増加拉よびこれに伴ら二次代謝活性化による着 色範囲の拡大が顕著であった，有傷無接種 21 日後でも着色 物質が観察され，付傷に対する反応と考兄られたが，同時 
期の接種個体と比較すると着色範囲は狭く, 接種個体では 傷よりも菌に対する防御反応として着色範囲が拡大してい ると考兄られた。 また, 有傷無接種 21 日後と接種 14 日後 を比べると, 水平方向では同程度の着色範囲であるのに対 し, 垂直方向では後者の方が着色範囲が広い. このことから， 接種 14 日後の時点で菌が宿主細胞に及汴す影響が表れてお り, 特に菌の分布密度が高くなりやすい垂直方向に拄いて それが顕著であることがわかった。

上記の防御反応に関して, 細胞レベルの知見としては以 下のことが明らかになった，宿主の生細胞である放射柔細 胞扣よび軸方向柔細胞の反応に注目すると, 接種 4 日後に は黄色の物質の蓄積があり, 7 日後には隣接する道管や木繊 維の壁も着色していたことから, 柔細胞から生成物が周囲 に渗出したことがわかる．また，7 日後には菌系が道管内か ら軸方向柔細胞と放射柔細胞内に壁孔を通じて侵入してい る. 本菌は生きた柔細胞にも侵入できること (Kajii et al., 2013）から，細胞内容物を吸収して利用していると推測さ れた。 な抒，二次代謝の活性化が起こっていても柔細胞内 に侵入していることから, 生成物の防御効果が不十分な可 能性があると考光られた，21日後まで，日数を経るにつれ て細胞内の着色物質は軸方向扤よび放射柔細胞に形成され, しかも色が淡黄色から黄色, 褐色へと濃色に変化していた ことから, 防御反応の範囲の拡大と同時に, 生成物の濃度 の上昇や酸化・重合などの化学変化が進んだと推測された (Hillis, 1987).

Holbrook and Zwieniecki（2005）は, 生細胞である柔細胞 は傷害を受けると，防御反応としてスベリンやフェノール 等の二次代謝産物を生合成・蓄積するとともに，柔細胞内 に貯蔵されていた糖類量は減少すると報告している. 本研 究に扔いても, 着色物質の蓄積が認めら机た柔細胞内では でんぷん粒の消失が確認され, でんぷんは防御物質生産の ための代謝に使われたと考光られる。なお，接種および付 傷穴の隣接部では柔細胞類に着色物質の蓄積がなく, でん ぷん粒が消失していなかったのは，ドリルによる穴開けの 際の物理的破壊によって細胞が壊死し, 二次代謝の活性化 に関与しなかったためと考兄られる。

葉の萎调が開始した時期に森田ら（2016）によって肉眼 レベルで判断された木部の変色部は, 本研究で観察された 二次代謝物質に起因寸る着色範囲と対応していた。 これら は虫媒伝染で萎调したイチジクで Kajii et al. (2013) が観察 した褐色〜黒褐色の変色拈よび細胞内の着色物質と同じで ある. 従って, 木部の変色は病原菌の活動に対する宿主柔 細胞の防御反応によって形成された傷害心材であり, 道管 は通水機能が停止している（Hillis, 1987）。また，変色部は，
葉の萎调開始時点で接種部の横断面に広範囲に広がってい ることが確認されたが，水平方向に菌の分布が拡大するこ とで横断面全体に変色が拡大したというょりも，複数の接 種穴から垂直方向に菌が拡大し，結果としてある横断面に 菌抢よび変色の分布が集まったと推測された. 森田ら (2016) の 1 点打よび 2 点有傷接種による予備試験では横断面上全 体に変色が広がらず枯死樹が発生しなかったことからも， 水平方向への変色拡大は活発でないと考光ら机る。な拉, 形成層特よび師部の柔細胞は, 葉の萎调が開始した段階で も, 変色部に接した部位以外では生存と判断されるものが 多数であった。一部の形成層や師部の壊死が樹木の枯死を 引き起こすことはなく（鈴木，1999），本病に抢ける萎调の 要因とは考觉られない。

接種部以外に，森田ら（2016）により菌の存在が確認さ れた範囲を観察した結果, 接種部では菌の分布密度が高かっ た一方で， $5 \mathrm{~cm}$ 離れた部位では菌の分布が一部の道管衫よ びその周囲の細胞のみと局所的であった，菌糸は空洞であ る道管内を介して容易に分布を広げるが, 細胞壁や生細胞 の防御反応を突破し分布密度を増加させるには日数がかか ると考兄られる。接種 7 日後に，接種部から $10 \mathrm{~cm}$ 離れた 菌検出部位で菌系などが観察されなかったのは, 極めて菌 の分布密度が低かったからだと推測された．以上のことか ら，枯死に至る要因として重要なことは，防御反応による 傷害心材形成部位，つまり通水停止部位が主幹の横断面上 で広がることであり，それが接種点付近のような局所的な 現象であっても十分であると結論ら゙けられる.

株枯病菌を接種していない有傷無接種個体では，傷に対 する防御反応がわずかに観察されたが，通水機能の停止お よび枯死が発生しなかったことから（森田ら，2016）, 本研 究程度の物理的傷害だけでは枯死に至らしめるほどの防御 反応や通水阻害は起こらないと言える。一方，ドリルでの 付傷により物理的に通水が停止した部位でもチロース充填 が認められた，チロースが充填された道管はすでに通水停 止していることが知られているため（島地・伊東，1982; Zimmermann, 1983)，充填された道管は通水停止していると 言える.

森田ら（2016）の通水機能の解析と, 本研究による内部 病徵の細胞レベルの観察結果から，株枯病菌接種によるイ チジク枯死の仕組みは, 以下のように推測される。(1接種 穴から，本菌の菌采が主に道管を介して伸長する。(2)道管 周囲の柔細胞類は防御反応を起こし, 黄〜茶褐色の物質が それらの細胞で生産され，細胞外一分泌される。それによっ て木部が変色し(傷害心材), 変色部では道管の通水機能が 停止する. (3)本菌の分布密度の上昇にともなって変色部が 
拡大し, 接種部付近の横断面で通水停止部分が増加する. (4)葉に届く水分量が著しく減少し, 葉に萎凋症状が発現し て枯死に至る。萎调個体では感染部位を中心に通水機能が 全面停止したことが明らかになった。この仕組みは，ナラ 枯れで示された「通水の停止した変色部の拡大により, 樹 幹のある高さに拈いて通水機能が全面停止する」といら発 病プロセス（黒田・山田，1996）ときわめて類似している. 隅田ら（2016）の土潩伝染に打ける発病プロセスの研究に より, 土壤伝染であっても主幹部の通水機能の停止と共に 葉の萎れが観察された。根の細胞に一部の壊死はあったが, 伝染経路に関わらず本病の発病要因として, 通導要素の機 能が阻害されて通水停止に至ることが重要であると推測さ れる。しかし，土壌伝染に打溌病プロセスについては 今後も詳細に検討する必要がある.

\section{謝辞}

本研究の一部は JSPS 科研費 JP25292089 の助成を受けて 行いました。

\section{摘 要}

イチジク株枯病は, 我が国のイチジク栽培地域で瞢延し ている病害であり, 枯死を引き起こす。本研究では, 株枯 病菌接種苗木の光学顕微鏡観察により, 宿主細胞内での本 菌の分布, 本菌が宿主細胞に及ぼす影響について検討し, 通水機能停止の過程について考察した. 接種 7 日後個体で は，接種部に扣いて菌糸が接種穴と隣接する道管执よびそ の周囲の軸方向柔細胞, 放射柔細胞, 木部繊維内に観察さ れた. 二次代謝の活性化に起因する着色物質は, 菌系の周 囲の軸方向柔細胞，放射柔細胞内执よび道管と木部繊維の 細胞壁にみられた。接種部より $5 \mathrm{~cm}$ 離れた部位では，菌糸 が道管扎よび周囲の柔細胞に局所的に観察された。着色物 質の蓄積も，接種部と比較するとごくわずかであった．萎 调開始個体の接種部では, 肉眼観察で確認された木部の変 色部に拈いて, 菌系が道管, 木部繊維, 軸方向拈よび放射 柔細胞，髄の細胞内に観察された。 また，菌糸が認められ た細胞抒よびその周囲の細胞内に，黄色〜褐色の着色物質 が観察された．形成層細胞内には，核が存在しているもの が多く観察され, 細胞の生存が認められた. 従って, 形成 層の壊死を経て葉の萎调が起こったとは考えられない. 森 田らの通水機能の解析と, 本研究による内部病徵の細胞レ ベルの観察結果から, 本菌接種によるイチジク枯死の仕組 みは, 以下のように推測される。(1)接種穴から, 本菌の菌
糸が主に道管を介して伸長する。(2)道管周囲の柔細胞類は 防御反応を起こし，黄〜茶褐色の物質を生産して分泌する. (3)本菌の分布拡大により変色部が拡大し, 接種部付近の横 断面で通水停止部分が増加する。（4)葉に届く水分量が著し く減少し，萎凋症状が発現して枯死に至る.

\section{引用文 献}

Feder, N. and O’Brien, T.P. (1968). Plant microtechnique: Some principles and new methods. Am. J. of Bot. 55: 123-139.

Hillis, W.E. (1987). Heartwood and Tree Exudates, pp. 157-162, Springer-Verlag, Berlin, Heidelberg, New York, London, Paris, Tokyo.

Holbrook, N.M. and Zwieniecki, M.A. (2005). Vasucular Transport in Plants, pp. 470-471, Elsevier Academic Press, San Diego, CA, U.S.A.

細見彰洋（2009）。抵抗性台木を用いたイチジク株枯病の防除. 農林水産技術研究ジャーナル 32: 31-33.

Kajii, C., Morita, T., Jikumaru, S., Kajimura, H., Yamaoka, Y. and Kuroda, K. (2013). Xylem dysfunction in Ficus carica infected with wilt fungus Ceratocystis ficicola and the role of the vector beetle Euwallacea interjectus. IAWA J. 34: 301-312.

梶谷裕二(1992)。福岡県に初発生したイチジク株枯病について. 日本植物病理学会報 58: 111-112. (講要)

梶谷裕二 (1996)。アイノキクイムシによるイチジク株枯病伝 搬の可能性. 日本植物病理学会報 62: 275. (講要)

瓦谷光男 - 三輪由佳 (2012). 農業総覧 原色病害虫診断防除 編 7. pp. 23-30, 農山漁村文化協会, 東京.

黒田慶子・山田利博（1996）。 ナラ類の集団枯損にみられる辺 材の変色と通水機能の低下. 日本林学会誌 78: 84-88.

新田浩通・森田剛成・岩崎由香・水主川桂宮 (2005)。 キクイ ムシによるイチジク株枯病の伝搬事例. 関西病虫研報 47: 95-98.

森田剛成・原 敬和・見世大作・軸丸祥大 (2012)。アイノキ クイムシが介在したイチジク株枯病の激害化事例. 関西病 虫研報 54: 29-34.

森田剛成・軸丸祥大・黒田慶子（2016）。株枯病菌を接種した イチジク苗木に打ける病徵の進展過程（1）木部の通水阻 害と萎调症状の関係. 日植病報 82: 301-309.

島地 謙・伊東隆夫 (1982)。図説木材組織. pp. 32-33, 地球社, 東京.

清水伸一・三好孝典・越智政勝・橘 泰宣（1999）。愛媛県に 打けるイチジク株枯病の発生とチオファネートメチル・ト リフルミゾール水和剂による防除. 愛媛果樹試験報 13: 27-35.

隅田泉月・森田剛成・黒田慶子 (2016)。イチジク株枯病菌 Ceratocystis ficicola の土㙥から宿主への侵入経路の解明. 樹 木医学研究 20: 30-31.

鈴木和夫（1999）。樹木医学. pp. 76-82, 朝倉書店，東京. 外側正之・増井伸一 - 野村明子 - 増井（塩崎）弘子 (1999). イチジク株枯れ症状の発生と防除. 静岡柑試研報 28: 51-62.

Zimmermann, M.H. (1983). Xylem structure and the ascent of sap. p. 143, Springer-Verlag, Berlin. 